\title{
Study on the Establishment of China-Russia Free Trade Zone under the One Belt And One Road Initiative
} Xiaoxun Guo ${ }^{1}$, Xiang $\mathrm{Li}^{2}$, and Feifei Wang ${ }^{3}$

Niagara University

USA

\section{ABSTRACT}

China's One Belt and One Road initiative is meaningful in building new types of international relations. China and Russia share similarities in their histories of development, industrial structures, and geographical locations, which are instrumental in building the China-Russia Free Trade Zone. However, the existing structure of the merchandise trade between the two countries lacks variety. Additionally, the protectionist trade policy creates barriers to the set-up of the China-Russia Free Trade Zone. Nevertheless, building the China-Russia Free Trade Zone promotes the development of One Belt and One Road and the common progress of China and Russia and benefits the whole world. Therefore, establishing One Belt and One Road-based China-Russia Free Trade Zone is presented with both opportunities and challenges.

\section{KEYWORDS: Free trade zones; a new type of international relation, China's economic policies}

\section{Introduction}

Since the launch of China's One Belt and One Road initiative, the number of participating countries has been increasing year by year. By the end of 2018, China had signed 170 intergovernmental cooperation documents with 122 countries and 29 international organizations, covering Asia, Africa, Europe, Oceania, and Latin America, and its influence has been gradually expanding. As an important cooperative partner of the initiative, Russia has close ties with China and is an important strategic collaborative partner of China. The bilateral trade between the two countries has been large and expanding. In 2018, the bilateral trade volume between China and Russia exceeded 100 billion US dollars for the first time. One Belt and One Road is the backdrop for establishing China-Russia free trade zone. The goal is to further expand the trade between the two countries, and promote mutual growth.

\section{Connections between One Belt and One Road and the Free Trade Zone (FTZ)}

\subsection{Internal Connections}

The One Belt and One Road initiative shares a similar background, theoretical value, and policy content with the FTZ strategy. First, world multi-polarization, economic integration, and trade liberalization have become the mainstream in the current social development. Based on this background, China formally announced the One Belt and One Road initiative in 2013, proposing "mutual discussion, mutual creation, and mutual sharing" as basic principles. The goal is to obtain reciprocal economic benefits and promote a green economy through strengthening cooperation among countries. Internationally, China and ten ASEAN countries formally established the ASEAN-China Free Trade Area (ACAFTA) in 2010. At home, China created the Shanghai Free Trade Zone in 2013 to promote the joint development of the regional economy, further facilitating the establishment of free trade zones. Therefore, One Belt and One Road and the FTZ are two forms of China's opening-up policy. Second, the strategic value of One Belt and One Road and the FTZ is mainly reflected in promoting regional economic integration, expanding the merchandise trade among countries, reducing regional differences, and actively building a community of shared future for humanity. Third, the One Belt and One Road initiative is based on "Five Links", namely, Policy Coordination, Infrastructure Development, Investment, and Trade Facilitation, Financial Integration, and Cultural and Social Exchange. The establishment of the FTZ is guided by new "Four Modernizations", namely, Investment Liberalization, Marketization of International Trade, Financial Internationalization, and Legalization of Administrative Regulations. The two approaches are similar in many ways in terms of their specific policy content.

\footnotetext{
1 Harbin Normal School, College of Economics, Niagara University. Email: guoxiaoxuan88@163.com, China

${ }^{2}$ Harbin Normal School, College of Economics, Niagara University Email: 1621140737@qq.com, China

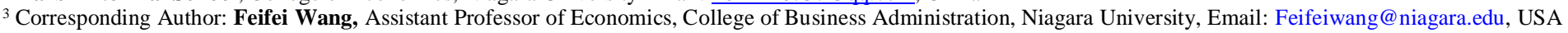




\title{
International Journal of Business and Applied Social Science
}

\author{
E-ISSN: 2469-6501 \\ VOL: 6, ISSUE: 3 \\ March/2020 \\ DOI:10.33642/fjbass.v6n3p2
}

CPER

Center for Promoting Education and Research (CPER) USA

WWW.cpernet.org

\subsection{External Connections}

One Belt and One Road and the FTZ progress together, promote each other and are closely related. The FTZ mainly relies on system innovation, tariff elimination, and quantitative restrictions, forming a series of advanced, convenient, and reproducible innovative systems represented by the Negative Lists system, and is a field experiment for One Belt and One Road and a critical window as well as a node for speeding up the promotion of One Belt and One Road, developing market economy, and creating a more open environment for economic growth. One Belt and One Road also foster the development of the FTZ, which is beneficial for deepening the understanding of other countries, and serves as the general guidance for the FTZ, hence providing the inexhaustible impetus for the development of the FTZ. One Belt and One Road and the FTZ will create economic growth for countries along the One Belt and One Road route.

\section{The Necessity of Establishing China-Russia Free Trade Zone under the One Belt and One Road Initiative}

\subsection{Long History}

China and Russia have a long history of interacting with each other. The unique relationship between the two countries is irreplaceable, which is mainly reflected in two aspects: first, Russia is the first country to establish the Friendly Cooperation with China after the founding of the People's Republic of China. 2019 marks the 70th anniversary of the formal establishment of diplomatic ties between the two countries. Second, the Hezhe ethnic group, one of China's 56 ethnic minorities, is closely related to the Nanai ethnic group in Russia. Historically, the two ethnic groups belong to the same ancestor. One of China's ethnic minorities, the Russian ethnicity, was the descendant of Soviet immigrants, now living in northern China and other places. Nowadays, the living habits, beliefs, and customs of the Hezhe and Russian ethnic groups in China still have many similarities with those in Russia. The frequent cultural exchanges between the two countries are conducive to deepening Russia's more comprehensive understanding of China.

\subsection{Favorable Location}

China belongs to the scope of Asia, while Russia spans Asia and Europe. In terms of geographical location, both countries are favorably located. China's land boundary is more than 22,000 kilometers. Russia is one of the fourteen countries bordering China and adjacent to northern China. In terms of territorial scope, Russia is the country with the largest landmass present, while China is ranked third in the world after Canada. China and Russia are large in area and adjacent in territory and have favorable locations.

\subsection{Policy Support}

Chinese and Russian leaders place great importance on communication and cooperation between the two countries. On 2019 June 23rd Xi Jinping, the general secretary of China, pointed out at the plenary session of St. Petersburg International Economic Forum that Russia is China's key and preferred partner, that China's the One Belt and One Road initiative and Russia's Greater Eurasian Partnership initiative are the same in principle, and that the two initiatives promote joint development of both countries. There are a large number of international organizations, strategies, and agreements in which China and Russia are both parts. In 1988, Shanghai of China and St. Petersburg of Russia formed a sister-city relationship for the first time. Since then, the number of twin cities developed by China and Russia has been gradually increasing. China and Russia successively joined the WTO in 2001 and 2012. Since then the bilateral trade volume has increased, and the economic interaction between the two countries has been on a rise. In 2014, China proposed to build China-Mongolia-Russia Economic Corridor to build links and promote communication in transportation. In 2015, the Eurasian Economic Union (EEU) was created by five founding countries, which include Russia and Belarus. In 2015, China and Russia made a joint statement on "Synergizing Cooperation between the Construction of the Silk Road Economic Belt and the Development of the EEU", providing policy support to the establishment of the China-Russia Free Trade Zone.

\subsection{Industrial Complementarily}

China is known for its large population with rich human resources and relatively cheap labor. China's industrial structure has advantages in labor-intensive industries but disadvantages in capital-intensive industries. Some resource-rich Chinese cities such as Daqing have been gradually losing their competitive edge since the founding of new China. China's demand for primary commodities rises, for example, the quantity of imported soybean has been large. In contrast, Russia mainly exports capital- 
intensive goods such as oil and natural gas and imports labor-intensive products. The two countries can create advantages in primary commodities through collaboration.

\section{Problems in Building China-Russia Free Trade Zone under One Belt and One Road}

\subsection{Russian Residents Have Little Understanding of One Belt and One Road}

Influenced by certain ethnic and historical factors, some Russian residents have relatively less understanding of One Belt and One Road. First, China consists of 56 ethnic groups of which most of them are ethnic minorities. Additionally, there is no unified system of religious beliefs and practices in China. Russia is mainly Russian in ethnicity, and most Russian people believe in orthodox. Second, from a historical perspective, the evolution of the Sino-Soviet and later the Sino-Russia relations has gone through many twists and turns. It mainly went through three stages: friendly and cooperative Sino-Soviet relation, worsening of Sino-Soviet relation leading to a split, and back-on-track normal China-Russia relation. Although Russia belongs to countries along the One Belt and One Road route, this route is only one of three Silk Road Economic Belt Routes. Moreover, China and Russia have different ethnicities and geographically belong to Asia and Europe, respectively. Due to these limitations, Russian people's understanding of One Belt One Road is not deep enough. As a result, they know very little about the positive effects brought about by the establishment of the China-Russia Free Trade Zone.

\subsection{Traded Goods Lack Variety}

As shown in table 1 and table 2, China is one of Russia's main trading partners. In 2018 alone, Russia's exports to China were worth 56.08 billion US dollars, and Russia's imports to China were 52.20 billion US dollars in value. The volume of the bilateral trade is large, accounting for significant portions of both countries' total imports and exports.

Table 1: Exports of Russia to the Top Five Trading Partners in 2018

\section{In Millions of US dollars}

\begin{tabular}{|c|c|c|c|}
\hline Country and region & Value & Percentage (\%) & Percentage as total (\%) \\
\hline Gross & 449,693 & 25.7 & 100.0 \\
\hline China & 56,076 & 44.1 & 12.5 \\
\hline Netherland & 43,516 & 22.2 & 7.7 \\
\hline Germany & 34,097 & 32.5 & 4.8 \\
\hline Belarus & 21,545 & 15.8 & 4.8 \\
\hline Turkey & 21,445 & 14.7 & 7.6 \\
\hline
\end{tabular}

(Source: China Ministry of Commerce website statistics country report, 2018)

Table 2: Imports of Russia to the Top Five Trading Partners in 2018 In Millions of US dollars

\begin{tabular}{|c|c|c|c|}
\hline Country and region & Value & Percentage (\%) & Percentage as total (\%) \\
\hline Gross & 237,424 & 4.4 & 100.0 \\
\hline China & 52,203 & 8.6 & 22.0 \\
\hline Germany & 25,505 & 5.3 & 10.7 \\
\hline America & 12,530 & -0.4 & 5.3 \\
\hline Belarus & 11,654 & -3.2 & 4.9 \\
\hline Italy & 10,572 & 4.7 & 4.5 \\
\hline
\end{tabular}

(Source: China Ministry of Commerce website statistics country report, 2018) 
In terms of the composition of imports and exports, Russia exported 42.71 billion of US dollars worth of mineral products (fossil fuels, mineral oils, and their products, bitumen) to China in 2018, accounting for 77.9 percent of their total exports. Russia imported 26.45 billion US dollars worth of mechanical and electrical products from China, accounting for $50.7 \%$ of the total imports. Among them, the total amount of light industrial products imported by Russia from China is significantly higher than that of similar products from other countries. The imports and exports between the two countries are concentrated in fixed types of resource-intensive products and primary products. Moreover, Russia's exports are influenced by natural and historical factors, consequently, it is easy to result in resource depletion once the resources get overexploited. Internationally, the proportion of services trade gradually surpasses goods trade. The composition of China-Russia imports and exports does not exhibit potential developmental advantages and lacks core competencies. Once the China-Russia Free Trade Zone gets built, the existing structure of bilateral trade will show a deficiency in international competitiveness in terms of trade volume and trade variety.

\subsection{Non-Tariff Barriers in Agriculture in Russia}

One of the purposes of the FTZ is to improve the degree of trade liberalization and reduce tariff and/or non-tariff barriers. In recent years Russia enacted Green Trade Barriers as main trade protection, and the most typical one is Green Trade Barriers used on agricultural products. Russia's economic development focuses on heavy industries. Energy and resource-based products are the most important export products in Russia. These industries have formed a scale economy and are less influenced by the outside world. Previously, Russia's agricultural development was in a weak position. In recent years, Russia has made progress in developing its agricultural sector followed by the increasing support from the Russian government. Especially, the Russian government takes advantage of Green Trade Barriers to protect its infant agricultural industries. Comparing to conventional protection policies, Green Trade Barriers are more convincing and more hidden. Based on a VAR model, Sun Hongyu and Tong Guangji (2019) concluded that Green Trade Barriers formulated by Russia would have a boycott effect on Chinese agricultural products exported to Russia, and the boycott effect will exist in the short term but will decrease in the long term.

\section{Approaches for China-Russia Free Trade Zone under One Belt and One Road}

\subsection{Improve Russian People's Understanding of One Belt and One Road}

To deepen Russian people understands of One Belt and One Road, we should think from the perspective of the historical background and their bilateral relations. First, China and Russia are similar in terms of historical background. China has a long history. The "Reign of Zhenguan" of the Tang Dynasty was the most glorious period in China's history. Realizing the great national rejuvenation is Chinese people's common wish ever since China's Reform and Opening-up. Stalin time was the most celebrated time of the former Soviet Union. Then the Soviet Union was the world's second-largest economy and a very influential country. Both countries are currently in the stage of national rejuvenation and share similar development background. Based on this, we should add more analysis of what the two countries have in common to improve Russian people's understanding of China and the history of China. Second, China and Russia should establish a closer cooperative relationship to foster joint economic development. The two countries need to take the China-Russia Free Trade Zone as a medium to increase the frequency of on-site cultural exchange and field trips. Furthermore, the two countries should publicize the China-Russia Free Trade Zone and One Belt and One Road in both China and Russia. Additionally, China needs to discuss with Russian representatives about building Chinese Confucius institutes in Russia and uses these institutes to deepen Russian people's understanding of China and learn of traditional Chinese culture. Moreover, China should use the cultural exchange as leverage to facilitate in-depth communication between Russian citizens and Chinese people, making Russian people realize that China has always been pursuing openness, inclusiveness and joint development intending to build a community of shared future for mankind together.

\subsection{Define Reform Key Points for China-Russia Free Trade Zone}

Reform key points should be clearly defined for China-Russia Free Trade Zone. Uniquely defined key points distinguish Chinese FTZ from other regional economic cooperation organizations in the world and maintain its special place on the international stage.

The key point of establishing China-Russia Free Trade Zone under One Belt and One Road is linking One Belt and One Road to China-Russia Free Trade Zone to promote innovation-based growth and further contribute to One Belt and One Road development with the establishment of the FTZ. Also, the complementarily advantage in industrial structures of China and Russia 


\title{
International Journal of Business and Applied Social Science
}

\author{
E-ISSN: 2469-6501 \\ VOL: 6, ISSUE: 3 \\ March/2020 \\ DOI:10.33642/ijbass.v6n3p2
}

CPER

WWW.cpernet.org

should be used to clarify reform key points and establish competitive advantages of China-Russia Free Trade Zone. Through defining the key points, we will further promote One Belt and One Road, stimulate economic development along the One Belt and One Road route, utilize preferential policies to the maximum, and foster the development of industrial structures of both China and Russia. Heilongjiang province of China has the best advantage in building the China-Russia Free Trade Zone. Heihe and Suifenhe of Heilongjiang trade frequently with Russia. According to a report by Heihe Daily on June 3, 2019, an experimental FTZ in Heilongjiang province was about to be approved, and Heihe was expected to lead the establishment of the China-Russia Free Trade Zone. Heilongjiang province has precious black soil regions, which is beneficial for agricultural development. Moreover, Heilongjiang province is adjacent to Russia and has a favorable location comparing to other regions, which effectively stimulates the China-Russia border tourism industry. The economic development of Heilongjiang province is critical to the revitalization of the old industrial base of Northeast China. Heilongjiang province continues its industrial transformation to revive the economic development within the province, attract foreign investment, drive the employment of the region, and lure outstanding graduates to come to Heilongjiang to work. Furthermore, the cultural exchange between China and Russia is quite common in this area. Many cultural exchange expositions have been held. Therefore, the China-Russia Free Trade Zone should be placed in Heilongjiang province with an emphasis on Heihe and Suifenhe. The reform key points are concentrated in cross-border agricultural trade, cross-border tourism, trade in services, industrial structural transformation, and national culture innovation, highlighting the advantages of China-Russia Free Trade Zone, promoting in-depth communication, changing the current bilateral trade model, and increasing the number of innovative trade programs with development potential.

\subsection{Strengthen Trade Regulatory System and Introduce Procedures for Opening up and Innovation in Financial Sector}

First of all, there exist regional economic cooperation organizations worldwide represented by EU, CAFTA, NAFTA, and the China-South Korea Free Trade Zone. The Africa Continental Free Trade Area agreement also took effect in May 2019. Regional economic cooperation organizations gradually attracted more attention. Establishing the China-Russia Free Trade Zone conforms to the current economic situation and trend. Additionally, within the borders of China, the development of the FTZ has hit a milestone. Since the establishment of the Shanghai Free Trade Zone, free trade zones in China added Guangdong, Tianjin, Fujian three free trade zones and further included Liaoning, Zhejiang, Henan, etc., seven other free trade zones. China has become increasingly matured in establishing free trade zones. Some Chinese fact-based innovation policies and systems were created with the main purpose of promoting trade liberalization. To reduce the negative impact of the trade protection policies on ChinaRussia Free Trade Zone, both countries should improve the trade supervision system development and issue open-up measures in financial innovation. First, China and Russia should hold further talks on topics of establishing China-Russia Free Trade Zone and increasing the bilateral trade volume and foreign investment. Additionally, borrowing experience from existing and influential free trade zones worldwide and combining with innovative measures produced in the creation of free trade zones within China to establish a relevant and feasible trade supervision system and roll out open-up financial innovation measures. Second, applying the "Negative Lists" system and the "Single Window" platform to the China-Russia Free Trade Zone to simplify the bilateral trade process and facilitate bilateral trade development. Regarding the already in-use tariff and non-tariff barriers by Russia, the two sides should communicate with each other to see whether they can cut back on the levels of the tariff or non-tariff barriers at the national level from the perspective of governments of the two countries. Third, Russia accumulates its RMB foreign exchange reserves, and China increases the holding of ruble foreign exchange reserves. In the meantime, adopting a unified currency (RMB or ruble) for the clearance of imports and exports to simplify the trade procedures and speed up the exchange. Fourth, both countries should conduct an early risk analysis of the China-Russia Free Trade Zone and propose detailed risk prevention measures.

\section{CONCLUSION}

To sum up, China and Russia have always been each other's most important trading partners. Both countries have favorable locations, similar economic development background, and complementary trade structure. Establishing the ChinaRussia Free Trade Zone boosts bilateral trade volumes, expands the degree of openness of the two countries, and stimulates 
economic development of Northeast China, the Russian Far East, and other regions, which is of considerable significance to the industrial structural transformation of the two countries.

\section{Acknowledgment}

Founding Project: Heilongjiang Provincial Philosophy and Social Science Planning Office project "Promoting the Research on the Long Village System and the Hezhe Nationality Construction of Beautiful Villages".(Project No. 18MZD342).

\section{REFERENCES}

Chenggang Wang (2012). Prediction of Russian trade barriers and their development trend[J]. Central Asian and eastern European markets of Russia. 4, 18-21.

Fang Yang (2018). "One Belt and One Road" cooperation, coordination and docking under China's free trade zone strategy[J]. Price monthly. 6, 72-75.

Han Zang, Liqun Fen (2019). Prospect research on the construction path of "One Belt and One Road"--based on the perspective of national welfare. Practice of Mathematics and Understanding[J]. 5, 128-142.

Hongyuan Chu, Zhao Yue, Yibo Song (2019). Research on construction of Heilongjiang province's free trade zone with Russia under the background of "One Belt And One Road"[J]. Commercial economy. 2, 12-14.

Hongyu Sun, Guangji Tong (2019). The impact of Russia's green trade barriers on Sino-Russian Agricultural Trade[J]. Jiangxi social sciences. 3, 77-85.

Lei Zhang, Chunxu Jia (2014). Feasibility analysis of establishing China-Russia free trade zone[J]. Economic Perspective. 10, $47-48+36$.

Linhui Zhu (2019). Overview of Russian trade in goods and bilateral trade between China and Russia in 2018. Webpage: http:// www.qianzhan.com/analyst/detail/220/190911-e12ee9e6.html.

Jinping Xi (2019). A speech at the BBS plenary session of the 23rd St. Petersburg International Economic Forum. Webpage: http://www.gov.cn/xinwen/2019-06/08/content_5398346.htm.

Shan Jiang (2019). Free trade zone construction may become a new starting point oF Heilongjiang reform[N]. China Business Times. 2019-06-10.

Zhizhong Liu (2017). Competition, complementarity and development potential of China-Russia bilateral trade under the "One

Belt And One Road" strategy[J]. Exploration of Economic Issues. 28, 195-202. 